\title{
Quo Vadis Higher Order Thinking Skills (HOTS) pada Soal UM-PIKIN Materi Pendidikan Agama Islam
}

\author{
Lilik Huriyah ${ }^{\text {a) }}$, Muhammad Fahmi ${ }^{\text {b) }}$, Rohaizan Baruc), Wahyu Ilaihi ${ }^{\text {d) }}$ \\ a) UIN Sunan Ampel Surabaya, Indonesia \\ b) UIN Sunan Ampel Surabaya, Indonesia \\ c) Universiti Sultan Zainal Abidin Terengganu, Malaysia \\ d) Tilburg University, Belanda
}

\section{ABSTRAK}

Input sumber daya manusia di perguruan tinggi dituntut untuk memiliki kemampuan berpikir tingkat tinggi (High Order Thinking Skills, HOTS) yang meliputi kemampuan menganalisis, mengevaluasi dan mengkreasi materi. Dengan demikian, keberadaan tes masuk perguruan tinggi menjadi salah satu intrumen penting dalam melakukan seleksi sumber daya manusia. Artikel ini bertujuan mengeksplorasi peta HOTS pada soal Ujian Masuk Perguruan Tinggi Keagamaan Islam Negeri (UM-PTKIN) materi Pendidikan Agama Islam (PAI) tahun 2018 dan perbandingan tingkat HOTS pada soal kelompok materi ujian PAl. Artikel ini juga didukung oleh hasil kajian kepustakaan. Hasil kajian menunjukkan bahwa item soal UM-PTKIN materi PAI berada pada kategori HOTS dan kemampuan berpikir tingkat rendah (Low Order Thinking Skill, LOTS). Materi Akidah Akhlak menjadi penyumbang terbanyak dan Al-Quran Hadith sebagai penyumbang paling sedikit pada soal kategori HOTS. Program Studi Pendidikan Agama Islam (PAI) adalah prodi yang sangat diminati sekaligus lulusannya sangat dinanti untuk dapat menyemai pemahaman keislaman untuk menjawab berbagai tantangan sosial, politik, dan keagamaan di Indonesia. Artikel ini memberikan rekomendasi bagi pemangku kebijakan UM-PTKIN untuk dapat meningkatkan jumlah komposisi soal HOTS dalam seleksi-seleksi selanjutnya agar dapat meningkatkan kualitas input mahasiswa PAI di periode-periode berikutnya.

\section{ABSTRACT}

Human resource input in higher education is required to have high order thinking skills (HOTS) which includes the ability to analyze, evaluate and create material. Thus, the existence of the college entrance test is one of the important instruments in selecting human resources. This article aims to explore the HOTS map on the Entrance Examination for State Islamic Religious Higher Education (UM-PTKIN) in the material of Islamic Religious Education (PAI) in 2018 and the comparison of HOTS levels in the PAI material group examination. This article is also supported by the results of a literature review. The results of the study show that the UM-PTKIN item on PAI material spreads in the HOTS category and lowlevel thinking skills (LOTS). Akidah Akhlak Subject is the largest contributor and AlQuran-Hadith as the lowest contributor to the HOTS category questions. The Islamic Religious Education Study Program (PAI) is a study program that is in great demand and its graduates are highly awaited to be able to sow Islamic understanding to answer various social, political and religious challenges in Indonesia. This article provides recommendations for UM-PTKIN policy makers to be able to increase the number of HOTS question compositions in subsequent selections in order to improve the quality of PAl student input in the following periods.

\section{KATA KUNCI}

Kemampuan Berpikir Tingkat

Tinggi; Soal UM-PTKIN;

Pendidikan Agama Islam.

KEYWORDS

Hingh Order Thinking Skills; UMPTKIN Item Tests; Islamic Education Subject. 
A. Pendahuluan

Pada era industri 4.0, Perguruan Tinggi harus siap bersaing dan meningkatkan mutunya. Salah satu ukuran mutu perguruan tinggi adalah nilai akreditasi yang ditetapkan oleh Badan Akreditasi Nasional Perguruan Tinggi (BAN-PT). BAN-PT menilai mutu perguruan tinggi melalui instrumen 9 kriteria. Kriteria pertama adalah visi, misi, tujuan dan sasaran. Kriteria kedua merupakan tata pamong, tata kelola dan kerjasama. Kriteria ketiga adalah mahasiswa. Kriteria keempat tentang Sumber Daya Manusia. Sedangkan kriteria kelima adalah Keuangan, sarana dan prasarana. Adapaun kriteria yang dinilai BANPT yang keenam adalah Pendidikan. Penelitian adalah kriteria yang ketujuh. Sedangkan kriteria kedelapan adalah pengabdian kepada masyarakat. Kemudian kriteria kesembilan yang menentukan sebuah perguruan tinggi bermutu atau tidak adalah luaran dan capaian tri dharma.

Salah satu kriteria yang terpenting adalah faktor mahasiswa. Untuk mewujudkan sebuah perguruan tinggi yang bermutu dan berdaya saing global, maka harus mempunyai mahasiswa yang bermutu pula. Mahasiswa yang bermutu dapat didapatkan dari excellent-nya proses pembelajaran di sebuah perguruan tinggi, ataupun dari faktor input mahasiswanya. Yang dimaksud input mahasiswa disini adalah calon mahasiswa yang masuk untuk menjadi mahasiswa di sebuah perguruan tinggi harus benar-benar bermutu, cerdas dan mempunyai daya nalar kritis yang tinggi. Sebagaimana dinyatakan Muhammad Fahmi bahwa proses rekrutmen adalah satu bentuk pengawalan sistem yang sangat penting bagi sebuah perguruan tinggi. ${ }^{1}$

Dalam rangka menjaring mahasiswa yang mempunyai daya nalar kritis yang tinggi, maka ada beberapa jalur yang dimiliki oleh perguruan tinggi sebagai pintu masuk para calon mahasiswanya. Berbagai jalur tersebut antara lain Seleksi Prestasi Akademik Nasional Perguruan Tinggi Keagamaan Islam Negeri (SPAN-PTKIN), Ujian Masuk Perguruan Tinggi Keagamaan Islam Negeri (UM-PTKIN), jalur mandiri, jalur beasiswa, serta berbagai jalur lainnya. Ambil misal satu jalur yakni jalur UM-PTKIN. Apakah mahasiswa yang dijaring melalui jalur ini memang benar-benar mahasiswa yang baik dan cerdas serta mempunyai daya nalar tinggi.

Terdapat beberapa penelitian yang membahas tentang HOTS dan soal ujian masuk perguruan tinggi. Diantaranya adalah penelitian Zaharil Anasy perihal HOTS (Higher Order Thinking Skill) in Reading Exercise. Penelitian dengan metode analisis isi, menjadikan obyek pertanyaan esai latihan membaca dalam buku teks Pathway to English textbook. Zaharil menyatakan bahwa ada ketidakseimbangan dalam distribusi keterampilan tingkat tinggi pada pertanyaaan esai membaca dalam buku tersebut. Menurutnya, kurangnya diberlakukan dengan baik keterampilan berpikir tingkat tinggi, terutama keterampilan yang tidak ada di pertanyaan membaca esai. Selanjutnya dalam penelitian ini juga

\footnotetext{
1 Muhammad Fahmi, "Tantangan interkoneksi Sains dan Agama di IAIN Sunan Ampel," Jurnal Pendidikan Agama Islam, Volume 02, Nomor 02 (November 2013), 320.
} 
ditemukan bahwa HOTS 'menganalisis' lebih banyak digunakan daripada HOTS keterampilan berpikir tingkat tinggi yang lainnya. ${ }^{2}$

Penelitian lain yang membahas tentang HOTS adalah penelitian Nurdinah Hanifah yang berjudul Pengembangan Instrumen Penilaian Higher Order Thinking Skill (HOTS) di Sekolah Dasar. Peserta didik akan memahami sebuah konsep jika mereka mempunyai kemampuan berpikir tingkat tinggi. Melalui penilaian, dapat diketahui sudahkah peserta didik memiliki keterampilan berpikir tingkat tinggi. Dalam rangka mengasah kemampuan berpikir peserta didik, penilaian tes adalah hal yang sangat tepat. Dia menyatakan bahwa mengapa peserta didik Indonesia HOTS-nya rendah jika dibanding dengan peserta didik dari luar negeri? Jawabannya adalah karena peserta didik Indonesia kurang dilatih untuk mengasah kemampuan berpikir tingkat tinggi. Sehingga para guru sudah seharusnya membuat instrumen penilaian yang mampu mengotimalkan dan mengasah kemampuan berpikir tingkat tinggi para peserta didik. Hanifah juga berupaya memberikan pandangan tentang pengembangan teknik penyusunan penilaian hasil belajar peserta didik yang bermuatan HOTS. ${ }^{3}$

Tak jauh dari penelitian sebelumnya, Nadlir dan Hanik Yuni Alfiyah meneliti pula tentang HOTS. Penelitan mereka berjudul Perbandingan Pendekatan Saintifik antara Kurikulum 2013 dan Pendekatan Burhani dalam Peningkatan Keterampilan Berpikir Tingkat Tinggi pada Mata Pelajaran Fiqih. Mereka menyandingkan dan membandingkan pendekatan burhani dan pendekatan saintifik atau pendekatan ilmiah dalam meningkatkan pemikiran tingkat tinggi keterampilan dalam mata pelajaran Fiqh. Sampel yang diambil adalah siswa MI Haji Hasyim Babat Pakal Surabaya sejumlah 18 siswa. Penelitian ini fokus pada pelaksanaan tahun akademik 2016/2017. Penelitian ini menemukan bahwa kedua pendekatan tersebut, yakni burhani dan saintifik, sama-sama dapat meningkatkan keterampilan berpikir tingkat tinggi dalam hal mengumpulkan informasi, menemukan tautan, menata ulang, dan mengembangkannya untuk menjawab pertanyaan. Penelitian ini juga membandingkan capaian kedua pendekatan tersebut. Hasilnya menyatakan bahwa pendekatan ilmiah Kurikulum 2013 ternyata lebih tinggi capaiannya jika dibandingkan dengan pendekatan Burhani. Akan tetapi hal ini berlaku untuk semua mata pelajaran, dan PAl adalah salah satu di antara beberapa mata pelajaran tersebut. ${ }^{4}$

Penelitian berikutnya yang mengkaji tentang HOTS adalah karya Tri Anjar yang berjudul Kesiapan Siswa SMA mengikuti Ujian Masuk Perguruan Tinggi dan Peran Konselor Sekolah. Ada beragam masalah saat para siswa bersiap mengikuti ujian masuk perguruan tinggi idamannya, baik masalah fisik, materi, maupun psikologis. Terlebih lagi hal ini sangat dirasakan oleh para peserta yang berasal dari sekolah swasta. Siswa dari sekolah swasta memiliki kecenderungan untuk rendah berdisiplin, serta kurang

\footnotetext{
2 Zaharil Anasy, "HOTS (Higher Order Thinking Skill) in Reading Exercise," TARBIYA: Journal of Education in Muslim Society, Volume 3 Number 1 (2016), 51-63.

${ }^{3}$ Nurdinah Hanifah, "Pengembangan Instrumen Penilaian Higher Order Thinking Skill (HOTS) di Sekolah Dasar, Current Research in Education" Conference Series Journal, Vol. 1, No. 1 (2019), 5.

${ }^{4}$ Nadlir dan Hanik Yuni Alfiyah, "Perbandingan Pendekatan Saintifik antara Kurikulum 2013 dan Pendekatan Burhani dalam Peningkatan Keterampilan Berpikir Tingkat Tinggi pada Mata Pelajaran Fiqih," Jurnal Pendidikan Agama Islam (Journal of Islamic Education Studies), Vol. 6 No. 1 (2018), 203.
} 
Lilik Huriyah, Muhammad Fahmi, Rohaizan Baru, Wahyu llaihi

semangat atau motivasi belajarnya. Tentunya hal ini sangat mempengaruhi tingkat kesiapan mereka untuk mengikuti ujian masuk perguruan tinggi dan berhasil lulus melewatinya. Tri Anjar berupaya untuk menemukan dan memaparkan kesiapan siswa SMA mengikuti ujian masuk perguruan tinggi dan peran guru BK/Konselor sekolah. Penelitian deskriptif kuantitatif ini dilakukan di SMA Muhammadiyah 1 Metro dengan jumlah siswa 212. Dari data yang dikumpulkan melalui angket, didapatkan hasil bahwa skor ratarata siswa adalah 80.53. Dari keseluruhan siswa yang tidak siap menghadapi ujian masuk perguruan tinggi sebanyak 26,84\%. Adapun Peran guru Bimbingan Konseling dalam penelitian ini dinyatakan dengan cara membuat program bimbingan sekolah lanjutan. Program ini ada dua macam, yakni dilakukan secara individual dan kelompok atau klasikal. Selain itu, guru Bimbingan dan Konseling SMA Muhammadiyah 1 Metro juga mengadakan program pembinaan dan pengembangan potensi anak. Bahkan guru BK melakukan peningkatan program ini dengan cara kerjasama dengan sesama guru dan wali murid siswa SMA Muhammadiyah 1 Metro. $^{5}$

Berikutnya seleksi masuk perguruan tinggi ini menjadi fokus penelitian Nur hasanah dan kawankawannya. Mereka melakukan penelitian kualitatif dengan judul Pengaruh Sistem Seleksi Masuk Perguruan Tinggi terhadap Indeks Prestasi Mahasiswa Jurusan Pendidikan Matematika Universitas Papua (UNIPA). Untuk bisa masuk ke UNIPA, ada beberapa jalur yang bisa ditempuh oleh para calon mahasiswa. Setelah mereka masuk di UNIPA, mereka akan belajar banyak mata kuliah dan setelah proses pembelajaran tersebut, dosen memberikan nilai pada mata kuliah yang diikutinya. Pada penelitian ini, Nurhasanah tertarik untuk mencari tahu apakah jalur masuk perguruan tinggi mempengaruhi nilai atau indeks prestasi mahasiswa di UNIPA. Penelitian ini dilakukan di Jurusan Pendidikan Matematika UNIPA. Dari data yang dikumpulkan, direduksi, dipaparkan, dan ditarik kesimpulan. Hasil penelitian menunjukkan bahwa tidak ada pengaruh antara Indeks Prestasi Kmulatif (IPK) mahasiswa dengan Jalur masuk ke UNIPA. IPK mahasiswa UNIPA dipengaruhi oleh kemampuan dasar tentang konsep matematika, kemauan memilih jurusan pendidikan matematika, ketertarikan pada matematika, serta metode belajar mereka. Nurhasanah berharap hasil penelitian ini bisa sebagai bahan masukan bagi jurusan pendidikan matematika. Selain hal tersebut, dia juga beharap agar penelitiannya dapat dijadikan alat evaluasi untuk dapat meningkatkan indeks prestasi mahasiswa. Bagi pimpinan di level UNIPA, hasil penelitan ini dapat memberi saran masukan untuk memperbaiki sistem seleksi mahasiswa UNIPA. ${ }^{6}$

Ada beberapa persamaan antara artikel ini dengan beberapa penelitian sebelumnya, yakni sama-sama membahas tentang HOTS, soal, dan persiapan masuk perguruan tinggi. Akan tetapi, dari penelitian terdahulu, belum ada yang membahas tentang tingkat HOTS dalam soal UMPTKIN materi

\footnotetext{
${ }^{5}$ Tri Anjar, "Kesiapan Siswa SMA mengikuti Ujian Masuk Perguruan Tinggi dan Peran Konselor Sekolah," Guidena, Vol 5 (June 2015), 50-64.

${ }^{6}$ Nurhasanah, Purwati, Herlina Ahmad, "Pengaruh Sistem Seleksi Masuk Perguruan Tinggi terhadap Indeks Prestasi Mahasiswa Jurusan Pendidikan Matematika Universitas Papua (UNIPA)," Prosiding Seminar Nasional, Volume 03 Nomor 1, 114.
} 
Agama. Padahal hal tersebut sangat penting, mengingat puluhan ribu calon mahasiswa mengikuti tes dan menjawab soal-soal UMPTKIN ini setiap tahunnya. Kekosongan tema penelitian inilah, yang mendorong penulis untuk meneliti Tingkat HOTS pada soal UMPTKIN Materi Pendidikan Agama Islam. Dalam penelitian ini penulis fokus pada dua hal. Pertama, fokus pada peta HOTS dalam soal UMPTKIN Materi Pendidikan Agama Islam. Dan yang kedua fokus pada tingkat perbandingan soal HOTS dalam Soal UM-PTKIN materi PAI yang terdiri dari 4 kelompok mata uji yakni Al Qur'an, Akidah Akhlak, Sejarah Kebudayaan Islam, dan Fiqih. Penelitian ini masih hanya meneliti tentang soal UMPTKIN materi Pendidikan Agama Islam, dengan pendekatan kepustakaan (library research) dan analisis isi (content analysis).

\section{B. Mengenal Higher Order Thinking Skills (HOTS) dan Lower Order Thinking Skills (LOTS)}

Sebelum membicarakan tentang HOTS, ada baiknya dibahas terlebih dahulu tentang tujuan pendidikan (taksonomi). Berbicara tentang tujuan pendidikan, tidak bisa terlepas dari taksonomi Bloom. Taksonomi Bloom merujuk pada taksonomi yang dibuat untuk tujuan pendidikan. Taksonomi ini pertama kali dirancang oleh Benjamin S. Bloom pada tahun 1956. Menurut Bloom, tujuan pendidikan dibagi menjadi beberapa domain. Setiap domain terdiri dari hirarki-hirarki yang lebih rinci.

Tujuan pendidikan dibagi ke dalam 3 domain, yaitu kognitif, afektif, dan psikomotorik. Domain kognitif, berisi perilaku-perilaku yang menekankan aspek intelektual, seperti pengetahuan, pengertian, dan keterampilan berpikir. Sedangkan domain afektif berisi perilaku-perilaku yang menekankan aspek perasaan dan emosi, seperti minat, sikap, apresiasi, dan cara penyesuaian diri. Adapun domain psikomotorik berisi perilaku-perilaku yang menekankan aspek keterampilan motorik seperti tulisan tangan, mengetik, berenang, dan mengoperasikan mesin. ${ }^{7}$

Seiring berjalannya waktu, pemikiran Benjamin S. Bloom ini direvisi oleh Anderson dan Krathwohl. Anderson dan Krathwohl merevisi dan memperkenalkan tentang berpikir tingkat tinggi atau Higher Order Thinking Skills (HOTS) pada tahun $2001 .{ }^{8}$ Pembaharuan ini sangat besar artinya, karena terdapat pergeseran penggunaan kata dalam taksonomi Bloom. Awalnya, Taksonomi Bloom menggunakan kata yang berbentuk kata benda, yakni pengetahuan, pemahaman, terapan, analisis, sintesis, dan evaluasi. Kata benda tersebut diubah menjadi kata kerja sehingga menjadi mengingat, memahami, menerapkan, menganalisis, mengevaluasi, dan mencipta. ${ }^{9}$

Selanjutnya, Anderson dan Krathwohl memetakan dan memeringkat taksonomi Bloom dari tingkatan terbawah hingga tingkatan teratas. Tingkatan kemampuan berpikir kognitif dari bawah ke atas adalah mengingat, memahami, mengaplikasikan, menganalisa, mengevaluasi dan mencipta. Tiga tingkatan pertama disebut juga sebagai berpikir tingkat rendah, yakni mengingat, memahami dan

\footnotetext{
7 Enggar, "Belajar Tiada Henti," Kata Kerja Operasional (Baru) Taksonomi Bloom dalam http://enggar.net/2016/06/kata-kerja-operasional-baru-taksonomi-bloom/(Diakses pada 20 Januari 2020).

8 Ibid.

${ }^{9}$ Basuki, MS Hariyanto, Asesmen Pembelajaran, (Bandung: PT Remaja Rosda karya, 2016), 12-14.
} 
mengaplikasikan. Sedangkan tiga tingkat berikutnya adalah berpikir tingkat atas, yakni menganalisis, mengevaluasi, dan mencipta. Taksonomi Bloom pada kegiatan berpikir menganalisis, mengevaluasi dan mengkreasi adalah tingkatan yang sama, yakni perpikir tingkat tinggi (Higher Order Thinking Skills). ${ }^{10} \mathrm{Di}$ beberapa referensi, dijelaskan bahwa berpikir tingkat tinggipun ada levelnya, yakni menganalisis, mengevaluasi, dan yang paling tinggi adalah mengkreasi, sebagaimana gambar 1 di bawah. ${ }^{11}$

Selanjutnya, tingkat berpikir kognitif Bloom ini dipetakan menjadi Higher Order Thinking Skills (HOTS) dan Lower Order Thingking Skills (LOTS) yang dapat digambarkan dalam diagram berikut ini:

Diagram 1. Taksonomi Bloom dalam skema HOTS dan LOTS ${ }^{12}$

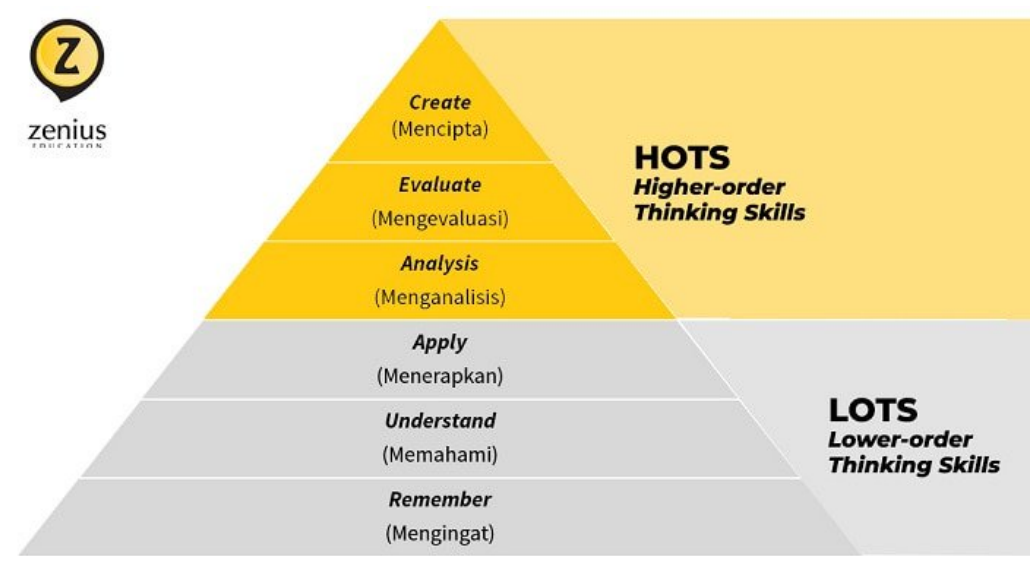

Dalam setiap level taxonomy Bloom, terdapat beberapa indikator yang menjelaskan masingmasing level. Pertama, level mengingat (Cognitif $1 / \mathrm{C} 1$ ). ${ }^{13}$ Dalam proses mengingat, sebagaimana dijelaskan Bloom bahwa 'peserta didik akan mengambil pengetahuan yang dibutuhkan dari memori jangka panjang. Jika tujuan pembelajarannya merupakan menumbuhkan kemampuan untuk meretensi materi pelajaran sama seperti materi yang diajarkan, maka mengingat adalah kategori kognitif yang tepat. Kedua, level memahami (C2). Proses memahami merupakan proses mengkontruksi makna dari pesan-pesan pembelajaran, yang disampaikan melalui pengajaran, buku, atau layar komputer. Peserta didik memahami ketika menghubungkan pengetahuan baru dan pengetahuan lama atau pengetahuan baru dipadukan dengan kerangka kognitif yang ada.

Level ketiga adalah mengaplikasikan (C3). Dalam level tiga kegiatan berpikir kognitif mengaplikasikan urutan langkah-langkah atau prosedur tertentu guna menjawab soal latihan atau memecahkan berbagai problem yang disuguhkan. Pilahan-pilahan ini meliputi dua kegiatan berpikir kognitif, yakni memilih dan menentukan tugas yang berbentuk soal latihan dan mengaplikasikan berbagai soal yang berupa problem-problem khusus yang tidak umum digunakan. Selanjutnya level keempat adalah menganalisis. Dalam proses menganalisis ini, peserta didik akan menggunakan proses

\footnotetext{
${ }^{10}$ Lorin W. Anderson and David R. Krathwohl, et.al., A Taxonomy for Learning, Teaching, and Assessing; A Revision of Bloom's Taxonomy of Educational Objectives, (New York: Addison Wesley Lonman Inc, 2001), 32.

${ }^{11}$ Fatkhan, Bloom's Taxonomy dalam http://fatkhan.web.id/taksonomi-bloom/ (Diakses pada 20 Januari 2020).

${ }^{12}$ Lorin W. Anderson, A Taxonomy for Learning, 32.

13 Ibid., 99-133.
} 
memecahkan masalah menjadi sub bagian kecil dan menentukan pola hubungan antar bagian dan struktur secara global. Pengelompokan kegiatan berpikir menganalisis ini terdiri dari kegiatan membedakan atau mencari perbedaannya, mengatur, serta mengatribusikan.

Sementara itu level kelima adalah mengevaluasi (C5). Mengevaluasi didefinisikan sebagai membuat keputusan berdasar kriteria dan standar. Kriteria-kriteria yang sering digunakan adalah kualitas, efektivitas, efisiensi, dan konsistensi. Masing-masing dari kriteria tersebut ditentukan oleh peserta didik. Standar yang digunakan bisa bersifat kuantitatif maupun kualitatif. Kategori mengevaluasi mencakup proses kognitif memeriksa (keputusan yang diambil berdasarkan kriteria internal) dan mengkritik (keputusan yang diambil berdasarkan kriteria eksternal).

Berikutnya adalah level higher order thinking skills yang tertinggi yakni mencipta (C6). Dalam proses mencipta, dikatakan Bloom bahwa peserta didik akan melibatkan proses menyusun elemenelemen menjadi sebuah keseluruhan yang koheren atau fungsional. Proses mencipta ini juga menuntut peserta didik membuat produk baru dengan mereorganisasi sejumlah elemen atau bagian menjadi suatu pola atau struktur yang tidak pernah ada sebelumnya. Proses kognitif yang terlibat dalam mencipta pada umumnya sejalan dengan pengalaman belajar yang telah dimiliki sebelumnya. Proses kognitif tersebut yaitu merumuskan, merencanakan dan memproduksi. ${ }^{14}$

Dalam rangka mempermudah para akademisi mengkategorisasi tingkatan berpikir ini, Anderson telah memetakan kata kerja operasional Taksonomi Bloom, mulai dari berpikir tingkat bawah hingga berpikir tingkat tinggi, sebagaimana dalam tabel 1 berikut ini. ${ }^{15}$

\footnotetext{
${ }^{14}$ Nur Astuti Puspaningtyas, Peningkatan Higher Order Thinking Skills (HOTS) melalui Startegi Pembelajaran Peningkatan Kemampuan Berpikir (SPPKB) pada Pembelajaran Ekonomi Kelas X SMK Muhammadiyah 1 Wates, Skripsi, (Surabaya: Universitas Negeri Yogyakarta, 2018), 22.

${ }^{15}$ Enggar, "Belajar Tiada Henti," Kata Kerja Operasional (Baru) Taksonomi Bloom dalam http://enggar.net/2016/06/kata-kerja-operasional-baru-taksonomi-bloom/ (Diakses pada 20 Januari 2020).
} 
Tabel 1. Taksonomi Bloom Hasil Revisi Anderson dan Krathwohl

\begin{tabular}{|c|c|c|c|c|c|c|}
\hline No & C1-pengetahuan & C2-pemahaman & C3-Aplikasi & C4- Analisis & C5- Evaluasi & C6-mengkreasi \\
\hline 1 & mengutip & Memperkirakan & Memerlukan & menganalisis & mempertimbangkan & mengabstraksi \\
\hline 2 & menyebutkan & Menjelaskan & Menyesuaikan & $\begin{array}{l}\text { Mengaudit / } \\
\text { memeriksa }\end{array}$ & menilai & menganimasi \\
\hline 3 & menjelaskan & mengkategorikan & Mengalokasikan & membuat blue-print & membandingkan & mengatur \\
\hline 4 & menggambar & Mencirikan & Mengurutkan & membuat garis besar & menyimpulkan & mengumpulkan \\
\hline 5 & membilang & Merinci & Menerapkan & memecahkan & mengkontraskan & mendanai \\
\hline 6 & mengidentifikasi & mengasosiasikan & Menentukan & Mengkarakteristikkan & mengarahkan & mengkategorikan \\
\hline 7 & mendaftar & membandingkan & Menugaskan & $\begin{array}{l}\text { membuat dasar } \\
\text { pengelompokan }\end{array}$ & mengkritik & mengkode \\
\hline 8 & menunjukkan & Menghitung & Memperoleh & merasionalkan & menimbang & mengkombinasikan \\
\hline 9 & memberi label & mengkontraskan & Mencegah & menegaskan & mempertahankan & menyusun \\
\hline 10 & memberi indeks & Mengubah & Mencanangkan & $\begin{array}{l}\text { membuat dasar } \\
\text { pengkontras }\end{array}$ & memutuskan & mengarang \\
\hline 11 & memasangkan & mempertahankan & Mengkalkulasi & Mengkorelasikan & memisahkan & membangun \\
\hline 12 & menamai & Menguraikan & Menangkap & mendeteksi & mempredikasi & menanggulangi \\
\hline 13 & menandai & Menjalin & Memodifikasi & mendiagnosis & menilai & menghubungkan \\
\hline 14 & membaca & Membedakan & Mengklasifikasikan & Mendiagramkan & memperjelas & menciptakan \\
\hline 15 & menyadari & Mendiskusikan & Melengkapi & Mendiversifikasi & merangking & mengkreasikan \\
\hline 16 & menghafal & Menggali & Menghitung & menyeleksi & menugaskan & mengkoreksi \\
\hline 17 & meniru & Mencontohkan & Membangun & $\begin{array}{l}\text { memerinci ke bagian- } \\
\text { bagian }\end{array}$ & menafsirkan & memotret \\
\hline 18 & mencatat & Menerangkan & Membiasakan & Menominasikan & $\begin{array}{l}\text { memberi } \\
\text { pertimbangan }\end{array}$ & merancang \\
\hline 19 & mengulang & Mengemukakan & Mendemonstrasikan & Mendokumentasikan & membenarkan & mengembangkan \\
\hline 20 & mereproduksi & Mempolakan & Menurunkan & Menjalin & mengukur & merencanakan \\
\hline 21 & meninjau & Memperluas & Menentukan & Menguji & memproyeksi & mendikte \\
\hline 22 & memilih & Menyimpulkan & Menemukan & mencerahkan & memerinci & meningkatkan \\
\hline 23 & menyatakan & Meramalkan & Menggambarkan & Menjelajah & menggradasi & memperjelas \\
\hline 24 & mempelajari & Merangkum & menemukan kembali & Membagankan & merentangkan & memfasiltasi \\
\hline 25 & mentabulasi & Menjabarkan & Menggunakan & Mengumpulkan & merekomendasikan & membentuk \\
\hline 26 & memberi kode & & Melatih & membuat kelompok & melepaskan & merumuskan \\
\hline 27 & menelusuri & & Menggali & Mengidentifikasi & memilih & menggeneralisasikan \\
\hline 28 & menulis & & Membuka & Mengilustrasikan & merangkum & menumbuhkan \\
\hline 29 & & & Mengemukakan & Menyimpulkan & mendukung & menangani \\
\hline 30 & & & membuat faktor & menginterupsi & mengetes & mengirim \\
\hline 31 & & & membuat gambar & menemukan & memvalidasi & memperbaiki \\
\hline 32 & & & membuat grafik & Menelaah & $\begin{array}{l}\text { membuktikan } \\
\text { kembali }\end{array}$ & menggabungkan \\
\hline 33 & & & Menangani & Menata & & memadukan \\
\hline 34 & & & Mengilustrasikan & Mengelola & & membatasi \\
\hline 35 & & & Mengadaptasi & Memaksimalkan & & menggabungkan \\
\hline 36 & & & Menyelidiki & Meminimalkan & & mengajar \\
\hline 37 & & & Memanipulasi & Mengoptimalkan & & membuat model \\
\hline 38 & & & Mempercantik & Memerintahkan & & Mengimprovisasi \\
\hline 39 & & & Mengoperasikan & Menggarisbesarkan & & membuat jaringan \\
\hline 40 & & & Mempersoalkan & memberi tanda/kode & & Mengorganisasikan \\
\hline 41 & & & & Memprioritaskan & & mensketsa \\
\hline 42 & & & & Mengedit & & Mereparasi \\
\hline
\end{tabular}

Dari tabel di atas, bisa diketahui bahwa salah satu berpikir tingkat tinggi level menganalisis (C4) adalah kegiatan menyimpulkan. Uji kemampuan menyimpulkan ini terlihat pada soal UMPTKIN tahun 2018 mata uji Akidah Akhlak soal nomor 62 yang berbunyi sebagai berikut: “Dalam sebuah wawancara tentang membina toleransi dari beragam penganut agama, seorang nara sumber mencontohkan kondisi riil keluarganya. Dia berkata, 'Orang yang meributkan agama adalah orang yang bodoh, bagi saya agama sama saja. Yang penting orangnya hidup benar. Saya wanita keturunan Jawa-Cina, keluarga besar saya mempunyai agama beraneka ragam, ada Kristen, Katholik, Buddha, Hindu, bahkan ada banyak yang masuk Islam tapi kami selalu rukun dan damai.' Soal: Tanggapan saudara dengan pernyataan ini adalah: ... (a). Pendapat tersebut secara umum muncul dari mereka yang tidak menginginkan kehidupan inharmonis karena keragaman agama di Indonesia. (b). Pendapat tersebut menunjukkan tingkat 
pemahaman yang masih kurang tentang perbedaan makna toleransi dan fanatik dalam beragama. (c). Pendapat itu mengaburkan makna toleransi dan mencampuradukkan ajaran agama. (d). Pendapat itu adalah sebuah harapan umum yang mestinya dipegangi para pemeluk agama yang berbeda untuk menciptakan suasana saling menghargai." ${ }^{16}$ Dari soal ini, para peserta diuji kemampuan menyimpulkan dari sebuah kasus yang dinarasikan dalam soal tersebut.

Berpikir tingkat tinggi level berikutnya adalah mengevaluasi (C5). Hal ini terlihat seperti dalam soal UMPTKIN mata uji Sejarah Kebudayaan Islam soal nomor 75. Bunyi soal tersebut adalah sebagai berikut: "Muhammad Zakariya al-Razi mengkritik teori Galen yang menyatakan penyakit disebabkan oleh ketidakseimbangan cairan atau sebagai hukuman Tuhan. Tokoh ini kemudian mengembangkan obat-obatan berdasarkan penyakit dan merawat pasien miskin secara gratis. Baghdad pada masa itu telah melaksanakan ujian kelayakan praktik dokter. Sikap al Razi mempresentasikan seorang Muslim: ... Pilihan jawaban: (a). Liberal karena membebaskan pasien-pasien miskin dari pegobatan mahal. (b). Humanis karena mengutamakan manusia sebagai subjek yang harus ditolong. (c). Sekuler karena mengembangkan kedokteran sebagi bagian ilmu duniawi. (d). Kritis karena menolak teori mapan yang diakui tanpa mengajukan bukti." ${ }^{17}$ Soal ini menuntut para peserta UMPTKIN untuk menafsirkan atau menilai sikap al Razi. Kemampuan berpikir menafsirkan atau menilai termasuk dalam level berpikir tingkat tinggi “mengevaluasi” (C5).

\section{Soal UM-PTKIN Materi Pendidikan Agama Islam}

Peserta didik yang sudah lulus sekolah tingkat Sekolah Menengah Atas (SMA) atau yang sederajat banyak yang menginginkan lanjut studi di perguruan tinggi. Ada banyak jalur masuk yang bisa dipilih oleh para calon mahasiswa. Beberapa diantaranya adalah jalur SNMPTN, SBMPTN, SPAN-PTKIN, UM-PTKIN, jalur mandiri, beasiswa, politeknik dan kedinasan. ${ }^{18}$ Mahasiswa bisa memilih salah satu atau beberapa jalur sekaligus dalam satu tahun ajaran.

Jalur pertama adalah jalur Seleksi Nasional Masuk Perguruan Tinggi Negeri (SNMPTN). SNMPTN dikenal juga sebagai jalur undangan. Pendaftar yang ingin ikut seleksi jalur ini syaratnya harus direkomendasikan oleh sekolah asalnya. Model penilaiannya adalah penilaian rapot sekolah. Jalur ini dapat diakses melalui situs resmi www.snmptn.ac.id. Jalur yang kedua adalah jalur Seleksi Bersama Masuk Perguruan Tinggi Negeri (SBMPTN). Jalur ini dibuka dengan sistem tes tertulis. Pendaftar bisa ikut seleksi dengan melakukan pendaftaran melalui situs resmi www.sbmptn.ac.id.

Jalur berikutnya adalah jalur Seleksi Prestasi Akademik Nasional Perguruan Tinggi Keagamaan Islam Negeri (SPAN-PTKIN). Jalur ini merupakan jalur undangan tanpa tes. Pendaftar bisa mengakses

\footnotetext{
${ }^{16}$ Dokumen Soal UMPTKIN tahun 2018.

17 Ibid.

${ }_{18}$ Pendaftaran mahasiswa baru dalam https://www.populer.web.id/2015/05/pendaftaran-mahasiswa-baru.html (Diakses pada 20 Januari 2020).
} 
situs resminya di span-ptkin.ac.id. Sedangkan untuk jalur tes adalah jalur UM-PTKIN (Ujian Masuk Perguruan Tinggi Keagamaan Islam Negeri). Adapun situs resminya bisa dilihat di um-ptkin.ac.id.

Selanjutnya jalur mandiri. Setiap kampus membuka jalur mandiri. Biasanya pendaftaran menggunakan sistem online, tetapi ada juga yang masih menggunakan manual dengan datang ke kampus untuk mengambil formulir pendaftaan. Info pendaftaran dapat dilihat melalui situs resmi kampus terkait. Jalur yang tak kalah terkenal dari jalur-jalur berikutnya adalah jalur Seleksi Penerimaan Mahasiswa Baru (SPMB). Ada beberapa Perguruan Tinggi Negeri dan Perguruan Tinggi Swasta tergabung dalam seleksi. Info pendaftaran SPMB bisa diakses melalui situs www.spmb.or.id.

Jalur berikutnya adalah jalur Politeknik. Jalur ini khusus untuk masuk ke Politeknik se-Indonesia. Biasanya seleksi jalur ini dilaksanakan pada awal tahun dan diikuti beberapa Politeknik terbaik di Indonesia. Untuk pendaftaran politeknik ini bisa diunduh di website resmi_politeknik.or.id. Jalur berikutnya adalah jalur Kedinasan. Bagi pendaftar yang ingin kuliah, dan setelah kuliah langsung kerja di bidang dan instansi terkait, maka jalur ini adalah pilihan yang tepat. Untuk pendaftaran dapat diakses melalui situs resmi dari masing-masing Perguruan Tinggi kedinasan. Jalur yang terakhir adalah jalur yang banyak diminati oleh sebagian calon mahasiswa, yakni jalur beasiswa. Ada banyak sekali beasiswa yang diberikan baik itu oleh pemerintah maupun non pemerintah. Beberapa contoh beasiswa adalah Beasiswa Bidikmisi, Beasiswa DIKTI, Beasiswa LPDP, Beasiswa PPA BBM, Beasiswa Djarum dan lain-lain. Beasiswa Bidikmisi bisa diakses melalui situs bidikmisi.belmawa.ristekdikti.go.id. Demikian pula jalur masuk beasiswa lainnya bisa diakses melalui unit terkait pemberi beasiswa.

Pada artikel ini, penulis hanya membahas soal-soal di jalur Ujian Masuk Perguruan Tinggi Keagamaan Islam Negeri (UM-PTKIN). Hal ini penulis lakukan, karena penulis akan mengulas secara detail soal-soal tentang Pendidikan Agama Islam. Lebih khusus lagi, penulis membatasi artikel ini pada soal UMPTKIN tahun 2018materi Pendidikan Agama Islam. Dalam soal UMPTKIN tahun 2018 terdiri dari soal Tes Kemampuan Dasar (TKD) dan Tes Kemampuan Bidang (TKB) yakni IPA atau IPS. Tes Kemampuan IPA diperuntukkan bagi mereka yang akan mengambil program studi eksak/IPA. Jadi bukan mereka yang masa SMAnya berada di jurusan IPA. Demikian pula Soal IPS diperuntukkan pendaftar yang memilih program studi humaniora atau IPS, dan bukan mereka yang semasa SMAnya mengambil jurusan IPS.

Dalam soal TKD terdapat beberapa soal yakni soal Tes Potensi Akademik (TPA), Bahasa Inggris, bahasa Arab, dan Keislaman atau Pendidikan Agama Islam (PAI). Soal TPA terdiri dari 35 soal, Bahasa Inggris terdapat 10 soal, Bahasa Arab terdiri dari 10 soal, dan Pendidikan Agama Islam sejumlah 45 soal. Sedangkan dalam soal PAI terdiri dari beberapa kajian yakni Al Qur'an Hadis, Akidah Akhlak, Sejarah Kebudayaan Islam (SKI) dan Fiqh. Adapun jumlah soal Tes Kemampuan Bidang (IPA/IPS) adalah 30 soal.

Selanjutnya, dalam artikel ini akan fokus di soal-soal PAl, yang terdiri dari 45 soal. Pada soal UMPTKIN tahun 2018, soal PAI menduduki soal nomor urut 56 hingga 100 pada soal TKD. Secara detail, gambaran soal UM-PTKIN tahun 2018 materi PAI adalah sebagai berikut: 
Tabel 2. Gambaran Soal-UM-PTKIN Tahun 2018 Materi PAI

\begin{tabular}{|c|c|c|c|c|}
\hline $\begin{array}{l}\text { No. } \\
\text { Urut }\end{array}$ & $\begin{array}{l}\text { No Soal } \\
\text { UM-PTKIN }\end{array}$ & Materi & Uraian & Soal \\
\hline 1. & 56. & Al Qur'an Hadis & Ayat Al Quran & $\begin{array}{l}\text { Ayat diatas menjelaskan tentang indikator iman yang benar yaitu } \\
\text { memadukan antara ... }\end{array}$ \\
\hline 2. & 57. & Al Qur'an Hadis & Ayat Al Quran & Ayat diatas menjelaskan tentang ketetapan Allah swt, yaitu bahwa ... \\
\hline 3. & 58. & Al Qur'an Hadis & Ayat Al Quran & $\begin{array}{l}\text { Ayat diatas memberikan bimbingan cara melaksanakan perilaku tolong } \\
\text { menolong, yaitu .... }\end{array}$ \\
\hline 4. & 59. & Al Qur'an Hadis & Hadis & $\begin{array}{l}\text { Dalam hadis tersebut, rasulullah saw melarang iri dengki (hasad), karena } \\
\text {... }\end{array}$ \\
\hline 5. & 60. & Al Qur'an Hadis & Al kisah & Pelajaran yang bisa diambil dari kisah Ali adalah .... \\
\hline 6. & 61. & Akidah Akhlak & Ayat al quran & Dapat ditarik sebuah hubungan bahwa .... \\
\hline 7. & 62. & Akidah Akhlak & $\begin{array}{l}\text { Pernyataan tentang } \\
\text { toleransi }\end{array}$ & Tanggapan saudara dengan pernyataan ini adalah .... \\
\hline 8. & 63. & Akidah Akhlak & Contoh kasus & Tanggapan saudara mensikapi kasus tersebut ..... \\
\hline 9. & 64. & Akidah Akhlak & Ayat al quran & $\begin{array}{l}\text { Ayat diatas mengajarkan hal yang yang paling berbahaya bagi orang } \\
\text { yang berperilaku riya yaitu ...... }\end{array}$ \\
\hline 10. & 65. & Akidah Akhlak & Narasi & $\begin{array}{l}\text { Secara teologi, yang menjadi sebab utama munculnya gerakan radikal } \\
\text { ini adalah .... }\end{array}$ \\
\hline 11. & 66. & Akidah Akhlak & Narasi & Hal itu bisa terjadi karena.... \\
\hline 12. & 67. & Akidah Akhlak & Contoh kasus & Berita seperti ini perlu adanya tabayyun, karena .... \\
\hline 13. & 68. & Akhlak & Ayat al quran & Hal ini mengajarkan adanya hubungan bahwa .... \\
\hline 14. & 69. & Akhlak & Contoh kasus & Menurut Saudara, karakter Honang adalah .... \\
\hline 15. & 70. & SKI & Sejarah sahabat & Kisah ini mengajarkan .... \\
\hline 16. & 71. & SKI & Kisah Rasulullah saw & Karakter dakwah Makkiyah dengan demikian .... \\
\hline 17. & 72. & SKI & Kisah Rasulullah saw & Karakter dakwah Madinah .... \\
\hline 18. & 73. & SKI & Kisah Khulafaur Rasyidin & Sang Khalifah ingin memberikan pelajaran kepada .... \\
\hline 19. & 74. & SKI & Kisah masa sahabat & Ciri kepemimpinan muslim harus mampu bersikap .... \\
\hline 20. & 75. & SKI & Kisah ilmuwan muslim & Sikap Al Razi merepresentasikan seorang muslim ... \\
\hline 21. & 76. & SKI & Kisah ilmuwan & $\begin{array}{l}\text { X dinobatkan sebagai peletak dasar ushul al fiqh, tertuang dalam kitab } \\
\text {... }\end{array}$ \\
\hline 22. & 77. & SKI & Kisah ilmuwan & Analogi kemajuan teknologi diatas pada zaman sekarang adalah .... \\
\hline 23. & 78. & SKI & $\begin{array}{l}\text { Kisah pemerintahan } \\
\text { islam }\end{array}$ & $\begin{array}{l}\text { Kemampuannya mengakulturasi budaya menciptakan peradaban Islam } \\
\text { India, misalnya ..... }\end{array}$ \\
\hline 24. & 79. & SKI & Narasi ajaran Islam & Klaim lokalitas Islam, seperti halnya di Swahili berikut .... \\
\hline 25. & 80. & SKI & Kisah sahabat & Strategi penyebaran Islam kontemporer memakai pola .... \\
\hline 26. & 81. & SKI & Kisah Rasulullah saw & Kisah tersebut relevan untuk membangun strategi dakwah .... \\
\hline 27. & 82. & SKI & Kisah muslim & $\begin{array}{l}\text { Masa depan tradisi damai ini masih relevan karena persaudaraan } \\
\text { masyarakat Indonesia didasarkan pada prinsip .... }\end{array}$ \\
\hline 28. & 83. & SKI & $\begin{array}{lll}\text { Sejarah Islam di } \\
\text { Indonesia }\end{array}$ & Dua terbitan tersebut menerapkan strategi dakwah ..... \\
\hline 29. & 84. & SKI & $\begin{array}{l}\text { Kisah cendekia muslim } \\
\text { Indonesia }\end{array}$ & $\begin{array}{l}\text { Jika dikaitkan dengan pola pikir kontekstual, pendirian MANPK } \\
\text { bertujuan mencetak generasi intelektual Islam Indonesia yang progresif } \\
\text {.... }\end{array}$ \\
\hline 30. & 85. & SKI & $\begin{array}{l}\text { Kisah cendekia muslim } \\
\text { Indonesia }\end{array}$ & $\begin{array}{l}\text { Implikasi pensyarahan ini menunjukkan bahwa ulama nusantara bervisi } \\
\text { global dengan kompetisi mampu .... }\end{array}$ \\
\hline 31. & 86. & Fiqh & Hadis Rasulullah saw & Hadis tersebut mengandung arti bahwa najis air liur anjing ... \\
\hline 32. & 87. & Fiqh & Contoh kasus & Konsekuensi keputusan Dewi tidak berpuasa adalah .... \\
\hline 33. & 88. & Fiqh & Narasi hokum & Yang termasuk mahram sementara adalah ..... \\
\hline 34. & 89. & Fiqh & Contoh kasus & Menurut anda, apa yang harus dilakukan oleh Syukri? \\
\hline 35. & 90. & Fiqh & Contoh kasus & Besaran zakat yang harus dikeluarkan adalah .... \\
\hline 36. & 91. & Fiqh & $\begin{array}{l}\text { Contoh kasus harta } \\
\text { waris }\end{array}$ & Cucu perempuan memperoleh bagian .... \\
\hline 37. & 92. & Fiqh & Contoh kasus & $\begin{array}{l}\text { Perilaku umat islam ini bertentangan dengan ajaran/hikmah puasa, } \\
\text { yaitu ..... }\end{array}$ \\
\hline 38. & 93. & Fiqh & Contoh kasus haji & Cara Zakir melaksanakan haji ini disebut .... \\
\hline 39. & 94. & Fiqh & Contoh kasus & Sikap Sarjan adalah ....... \\
\hline 40. & 95. & Fiqh & Contoh kasus & Bentuk kerjasama keduanya adalah .... \\
\hline 41. & 96. & Fiqh & Contoh kasus & Istri Kamil yang diceraikan ini harus beriddah selama .... \\
\hline 42. & 97. & Fiqh & Contoh kasus & Kerjasama Ahmad dan Zaki tersebut merupakan transaksi ... \\
\hline 43. & 98. & Fiqh & Contoh kasus & $\begin{array}{l}\text { Sikap presiden tersebut termasuk dalam kewajiban pemimpin berkaitan } \\
\text { dengan .... }\end{array}$ \\
\hline 44. & 99. & Fiqh & Contoh kasus & Transaksi jual beli tersebut dipandang ........ \\
\hline 45. & 100. & Fiqh & Contoh kasus & Jual beli bentuk barter ini termasuk ............ \\
\hline
\end{tabular}


Lilik Huriyah, Muhammad Fahmi, Rohaizan Baru, Wahyu llaihi

\section{Menakar HOTS pada Soal UM-PTKIN Tahun 2018 Materi PAI}

Untuk mengetahui tingkatan Higher Order Thinking Skills (HOTS) soal UM-PTKIN Tahun 2018 materi PAI, maka harus dilakukan analisis, pemetaan serta pengklasifikasian satu persatu dari soal tersebut. Dari uraian paparan subjudul sebelumnya dinarasikan deskripsi soal UM-PTKIN Tahun 2018 materi PAI. Jika soal itu dipetakan berdasarkan tingkat berpikir kognitif taksonomi Bloom yang direvisi oleh Alexander dan Krathwohl, maka dapat dilihat pada table berikut ini:

Tabel 3. Tingkat Berpikir Kognitif Soal UM-PTKIN Materi PAI

\begin{tabular}{|c|c|c|c|c|c|c|c|c|c|c|}
\hline \multirow{2}{*}{$\begin{array}{l}\text { No. } \\
\text { Urut } \\
\text { Soal }\end{array}$} & \multirow[t]{2}{*}{ Materi } & \multirow[t]{2}{*}{ Kompetensi } & \multicolumn{6}{|c|}{ Tingkat Berpikir Kognitif } & \multicolumn{2}{|l|}{ Kategori } \\
\hline & & & C1 & C2 & C3 & C4 & C5 & C6 & LOTS & HOTS \\
\hline 1 & Al Quran & Merangkum & & $\sqrt{ }$ & & & & & $\mathrm{V}$ & \\
\hline 2 & Al Quran & Menerangkan & & $\mathrm{V}$ & & & & & $\mathrm{V}$ & \\
\hline 3 & Al Quran & Menentukan & & & $\mathrm{V}$ & & & & $\mathrm{V}$ & \\
\hline 4 & Al Quran & Menentukan & & & $\mathrm{V}$ & & & & $\mathrm{V}$ & \\
\hline 5 & Al Quran & Menyimpulkan & & & & $\mathrm{V}$ & & & & $\sqrt{ }$ \\
\hline 6 & Akidah Akhlak & Mengkorelasikan & & & & $\sqrt{ }$ & & & & $\sqrt{ }$ \\
\hline 7 & Akidah Akhlak & menelaah, menemukan & & & & $\mathrm{V}$ & & & & $\mathrm{V}$ \\
\hline 8 & Akidah Akhlak & Mendiagnosis & & & & $\mathrm{V}$ & & & & $\mathrm{V}$ \\
\hline 9 & Akidah Akhlak & Menguraikan & & $\mathrm{V}$ & & & & & $\mathrm{V}$ & \\
\hline 10 & Akidah Akhlak & Menganalisis & & & & $\mathrm{V}$ & & & & $\sqrt{ }$ \\
\hline 11 & Akidah Akhlak & Menyimpulkan & & & & & $\mathrm{V}$ & & & $\sqrt{ }$ \\
\hline 12 & Akidah Akhlak & Menilai & & & & & $\mathrm{V}$ & & & $\sqrt{ }$ \\
\hline 13 & Akidah Akhlak & Mengkorelasikan & & & & $\mathrm{V}$ & & & & $\mathrm{V}$ \\
\hline 14 & Akidah Akhlak & Menyimpulkan & & & & & $\mathrm{V}$ & & & $\sqrt{ }$ \\
\hline 15 & SKI & Merasionalkan & & & & $\mathrm{V}$ & & & & $\sqrt{ }$ \\
\hline 16 & SKI & Merasionalkan & & & & $\mathrm{V}$ & & & & $\sqrt{ }$ \\
\hline 17 & SKI & Merasionalkan & & & & $\mathrm{V}$ & & & & $\mathrm{V}$ \\
\hline 18 & SKI & Menyimpulkan & & & & & $\mathrm{V}$ & & & $\mathrm{V}$ \\
\hline 19 & SKI & Menyimpulkan & & & & & $\mathrm{V}$ & & & $\mathrm{V}$ \\
\hline 20 & SKI & menafsirkan/menilai & & & & & $\mathrm{V}$ & & & $\sqrt{ }$ \\
\hline 21 & SKI & Menghafal & $\mathrm{V}$ & & & & & & $\mathrm{V}$ & \\
\hline 22 & SKI & Mengkorelasikan & & & & $\sqrt{ }$ & & & & $\sqrt{ }$ \\
\hline 23 & SKI & Mencontohkan & & $\mathrm{V}$ & & & & & $\mathrm{V}$ & \\
\hline 24 & SKI & Mengkarakteristikkan & & & & $\mathrm{V}$ & & & & $\mathrm{V}$ \\
\hline 25 & SKI & Menyimpulkan & & & & & $\mathrm{V}$ & & & $\mathrm{V}$ \\
\hline 26 & SKI & Mengkorelasikan & & & & $\sqrt{ }$ & & & & $\sqrt{ }$ \\
\hline 27 & SKI & Menyimpulkan & & & & & $\mathrm{V}$ & & & $\mathrm{V}$ \\
\hline 28 & SKI & Menyimpulkan & & & & & $\mathrm{V}$ & & & $\mathrm{V}$ \\
\hline 29 & SKI & Membandingkan & & & & & $\mathrm{V}$ & & & $\mathrm{V}$ \\
\hline 30 & SKI & Menyimpulkan & & & & & $\mathrm{V}$ & & & $\mathrm{V}$ \\
\hline 31 & Fiqih & Menjelaskan & & $\mathrm{V}$ & & & & & $\mathrm{V}$ & \\
\hline 32 & Fiqih & Memprediksi & & & & & $\mathrm{V}$ & & & V \\
\hline 33 & Fiqih & Memutuskan & & & & & $\mathrm{V}$ & & & $\mathrm{V}$ \\
\hline 34 & Fiqih & Memutuskan & & & & & $\mathrm{V}$ & & & $\mathrm{V}$ \\
\hline 35 & Fiqih & Menghitung & & $\mathrm{V}$ & & & & & $\mathrm{V}$ & \\
\hline 36 & Fiqih & Menghitung & & $\mathrm{V}$ & & & & & $\mathrm{V}$ & \\
\hline 37 & Fiqih & Memutuskan & & & & & $\mathrm{V}$ & & & $\mathrm{V}$ \\
\hline 38 & Fiqih & Mencirikan & & $\mathrm{V}$ & & & & & $\mathrm{V}$ & \\
\hline 39 & Fiqih & Menyimpulkan & & & & & $\mathrm{V}$ & & & $\mathrm{V}$ \\
\hline 40 & Fiqih & Memutuskan & & & & & $\mathrm{V}$ & & & $\sqrt{ }$ \\
\hline 41 & Fiqih & Menominasikan & & & & $\mathrm{V}$ & & & & $\mathrm{V}$ \\
\hline 42 & Fiqih & Menominasikan & & & & $\mathrm{V}$ & & & & $\mathrm{V}$ \\
\hline 43 & Fiqih & Mengkorelasikan & & & & $\mathrm{V}$ & & & & $\mathrm{V}$ \\
\hline 44 & Fiqih & Menyimpulkan & & & & & $\mathrm{V}$ & & & $\mathrm{V}$ \\
\hline \multirow[t]{3}{*}{45} & Fiqih & Menyimpulkan & & & & & $\mathrm{V}$ & & & $\mathrm{V}$ \\
\hline & & Jumlah & 1 & 8 & 2 & 15 & 19 & 0 & 11 & 34 \\
\hline & & Persentase & $2,2 \%$ & $\begin{array}{c}17,8 \\
\%\end{array}$ & $4,4 \%$ & $33,3 \%$ & $42,2 \%$ & $0 \%$ & $24,4 \%$ & $75,6 \%$ \\
\hline
\end{tabular}

Keterangan Tabel 3:
$\mathrm{C} 1$ = Menghafal
C2 = Memahami C3 = Mengaplikasi
C4 = Menganalisis
C5 = Mengevaluasi
C6 $=$ Mengkreasi LOTS $=\mathrm{C} 1, \mathrm{C} 2, \mathrm{C} 3$ HOTS $=\mathrm{C} 4, \mathrm{C} 5, \mathrm{C} 6$ 
Dari data di atas diketahui bahwa tingkat kompetensi soal UM-PTKIN materi Pendidikan Agama Islam menyebar mulai dari C1, C2, C3, C4 hingga C5. Tidak terlihat satu soalpun pada level kompetensi C6. Soal materi PAI diwarnai dengan soal-soal level tinggi, yakni C5 terdapat 19 soal atau mencapai 42,2 \% dan soal level C4 terdiri dari 15 butir soal atau setara dengan 33,33\%. Soal lain yang rendah adalah level C1, yakni terdapat 1 soal saja di kajian al Qur'an Hadis. Diagram tingkatan kompetensi soal UMPTKIN materi PAI bisa terlihat sebagai berikut:

Diagram 2. Tingkatan Kompetensi Soal UM-PTKIN Materi PAI

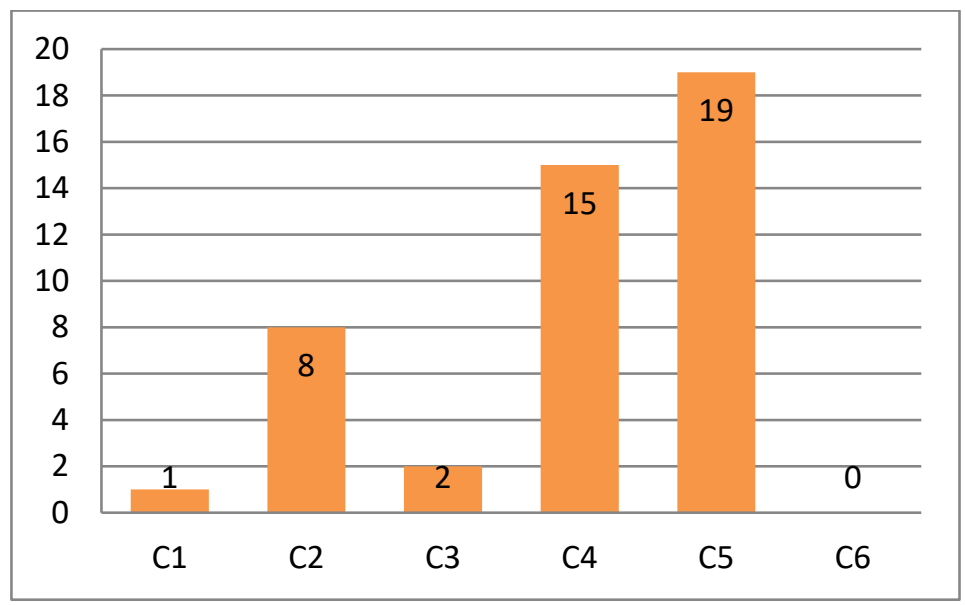

Jika dilihat dari sisi soal-soal dengan Higher Order Thinking Skill (HOTS) dan Lower Order Thinking Skill (LOTS), maka dari data yang dipaparkan sebelumnya, soal UM-PTKIN materi PAI lebih banyak HOTSnya daripada soal soal LOTS. Keseluruhan jumlah soal PAI dalam UMPTKIN adalah 45 butir soal. Adapun soal HOTSnya berjumlah 34 butir soal yang setara dengan 75,6 \%. Sedangkan soal-soal berlevel LOTS pada soal UMPTKIN materi PAI pada tahun 2018 berjumlah 11 yang setara dengan 24,4 \%. Berikut diagram pie persentase soal HOTS UMPTKIN tahun 2018 materi PAI.

Tabel 4. Tingkat Kompetensi Soal UM-PTKIN Materi PAI Perkajian Bidang IImu

\begin{tabular}{|c|c|c|c|c|c|c|c|c|c|}
\hline \multirow[t]{2}{*}{ Materi } & \multirow{2}{*}{$\begin{array}{l}\text { Jumlah } \\
\text { Soal }\end{array}$} & \multicolumn{6}{|c|}{ Level Kognitif } & \multicolumn{2}{|c|}{ Kategori } \\
\hline & & C1 & $\mathrm{C2}$ & C3 & C4 & C5 & C6 & LOTS & HOTS \\
\hline al Qur'an Hadis & 5 & 0 & $\begin{array}{l}2 \\
\text { (40\%) }\end{array}$ & $2(40 \%)$ & $1(20 \%)$ & 0 & 0 & $\begin{array}{l}4 \\
(80 \%)\end{array}$ & $\begin{array}{l}1 \\
(20 \%\end{array}$ \\
\hline Akidah Akhlak & 9 & 0 & $\begin{array}{l}1 \\
(11 \%)\end{array}$ & 0 & $\begin{array}{l}5 \\
(56 \%)\end{array}$ & $\begin{array}{l}3 \\
(33 \%)\end{array}$ & 0 & $\begin{array}{l}1 \\
(11 \%)\end{array}$ & $\begin{array}{l}8 \\
(89 \% \\
\end{array}$ \\
\hline SKI & 16 & $\begin{array}{l}1 \\
(6 \%)\end{array}$ & $\begin{array}{l}1 \\
(6 \%) \\
\end{array}$ & 0 & $\begin{array}{l}6 \\
(38 \%)\end{array}$ & $\begin{array}{l}8 \\
(50 \%) \\
\end{array}$ & 0 & $\begin{array}{l}2 \\
(12 \%)\end{array}$ & $\begin{array}{l}14 \\
(88 \%)\end{array}$ \\
\hline Fiqih & 15 & 0 & $\begin{array}{l}4 \\
(27 \%) \\
\end{array}$ & 0 & $\begin{array}{l}3 \\
(20 \%) \\
\end{array}$ & $\begin{array}{l}8 \\
(53 \%) \\
\end{array}$ & 0 & $\begin{array}{l}4 \\
(27 \%) \\
\end{array}$ & $\begin{array}{l}11 \\
(73 \% \\
\end{array}$ \\
\hline
\end{tabular}

Dari Tabel 4 di atas, dapat diketahui bahwa soal UM-PTKIN Tahun 2018 materi PAI belum semuanya termasuk soal ketegori HOTS. Soal kategori LOTS masih ada, yakni tepatnya Kognitif level 1 (C1) yakni menghafal, yang terdapat pada 1 soal bidang kajian Sejarah Kebudayaan Islam. Adapun soal yang masih level C2 terdapat 8 butir soal yang tersebar pada soal materi PAI semua bidang kajian ilmu yakni Al Qur'an Hadis, Akidah, SKI dan Fiqih. Soal level C3 ditemukan sejumlah 2 butir soal, yakni soal di 
bidang kajian Al Qur'an Hadis. Soal level C4 yakni level HOTS, terdiri dari 15 butir soal yang tersebar di semua bidang kajian ilmu materi PAI. Soal level C5 atau mengevaluasi berjumlah 19 soal, yakni ada dalam kajian ilmu Akidah Akhlak, SKI, dan Fiqh. Tidak terdapat level C5 di kajian al Qur'an hadis. Sedangkan soal level C6 sama sekali belum ada di semua kajian bidang ilmu baik SKI, al Qur'an Hadis, Akidah Akhlak, maupun Fiqih. Tingkat Kompetensi (C1-C6) Soal UMPTKIN Materi PAI perkajian Bidang Ilmu bisa dilihat pada diagram 3.

Diagram 3. Peta Tingkat HOTS Soal UM-PTKIN Tahun 2018 Materi PAI per Mata Uji

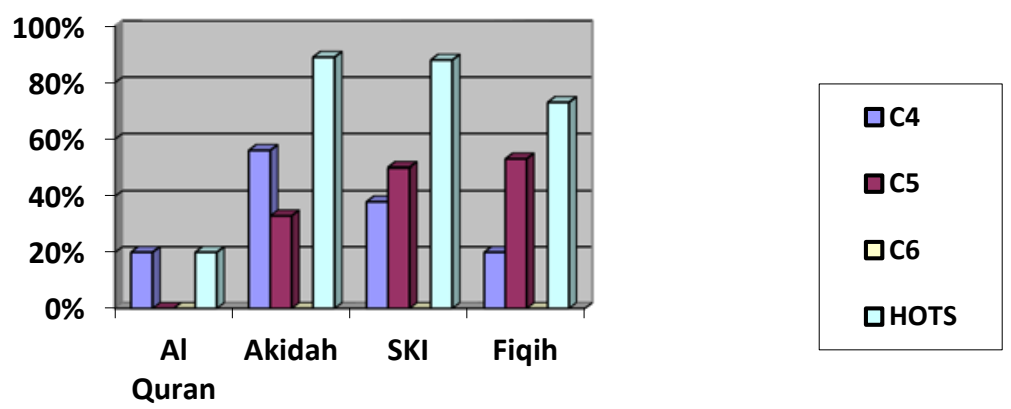

Dari diagram di atas dapat diketahui bahwa soal UM-PTKIN Tahun 2018 materi PAI kajian tentang Akidah Akhlak adalah penyumbang terbesar yang menyuguhkan soal-soal HOTS. Soal Akidah Akhlak yang masuk dalam kategori HOTS mencapai 89\%, disusul kemudian dengan kajian tentang Sejarah Kebudayaan Islam yang memberikan soal HOTS berjumlah $88 \%$. Peringkat penyumbang soal HOTS berikutnya adalah materi PAI kajian tentang Fiqh yang mencapai $73 \%$, dan yang paling sedikit adalah soal HOTS adalah kajian AI Qur'an Hadis yang mencapai $20 \%$. Sedangkan soal-soal LOTS atau berpikir tingkat rendah sangat banyak dalam soal al Qur'an Hadis yang mencapai $80 \%$. Sedangkan kajian yang lainnya relatif sedikit soal-soal LOTSnya, yakni Akidah Akhlak 11\%, SKI hanya berkisar $12 \%$, dan Fiqh mencapai $27 \%$. Tentunya hal ini harus dilakukan perbaikan soal-soal UM-PTKIN Materi PAI untuk tahuntahun berikutnya.

Dari pembahasan di atas, seharusnya soal-soal UMPTKIN menggunakan soal yang berlevel HOTS dan tidak lagi menggunakan soal-soal LOTS. Banyaknya soal-soal LOTS yang masih terlihat di beberapa soal UMPTKIN Tahun 2018 terlihat jelas dari soal Al Quran hadis yang masih menguji kemampuan 'merangkum' peserta UMPTKIN. Disamping itu juga masih ada soal yang menguji kemampuan 'menghafal' peserta UMPTKIN seperti tertulis pada soal UMPTKIN mata uji Sejarah Kebudayaan Islam. Diharapkan pada tahun-tahun berikutnya soal LOTS tidak muncul lagi dalam soal UMPTKIN. Hasil penelitian penulis ini relevan dengan hasil penelitian Nurdinah Hanifah tentang Pengembangan Instrumen Penilaian Higher Order Thinking Skill (HOTS). Melalui sebuah penilaian dengan instrument penilaian yang HOTS, dapat diketahui sudahkah peserta didik memiliki keterampilan berpikir tingkat tinggi. Dalam rangka mengasah kemampuan berpikir peserta didik, penilaian tes adalah hal yang sangat 
tepat. ${ }^{19} \mathrm{Hal}$ ini sangat tepat dilakukan oleh sebuah perguruan tinggi dalam rangka menjaring calon mahasiswanya melalui jalur UM-PTKIN.

\section{E. Quo Vadis HOTS pada Soal-soal UM-PTKIN}

Berpikir (thinking) merupakan sebuah keterampilan yang bertujuan untuk meningkatkan konstruksi pemahaman yang lebih dalam dan didorong secara konseptual. ${ }^{20}$ Term ini mengandung makna yang beragam. Untuk mengilustrasikan kompleksitas tersebut Webster Encyclopedic Unabridged Dictionary (2001) memberikan banyak definisi tentang berpikir yang mencakup aktivitas yang meliputi menahan kesadaran, mengingat, membuat keputusan rasional, mengevaluasi informasi, menyusun ide, membuat rencana, mengevaluasi tindakan, dan mengasah ketajaman berpikir atau analisis mendalam. ${ }^{21}$

Kandungan HOTS dalam soal UM-PTKIN sangat penting mengingat atmosfer peradaban manusia tengah memasuki era 5.0. Pandemi Covid-19 yang melanda berbagai negara, tidak terkecuali Indonesia meniscayakan HOTS dalam memfilter derasnya arus informasi yang masuk. Jika HOTS mulai dari C1 sampai C6 -terutama C6- tidak diinput dalam soal UMPTKIN, bukan tidak mungkin para mahasiswa sebagai agent of change akan menjadi generasi yang lumpuh baik secara kognitif, afektif maupun psikomotorik. Dalam konteks ini, implementasi HOTS dalam soal UM-PTKIN menemukan titik signifikansinya.

HOTS secara ringkas mengandung aspek tiga hal, yaitu validitas konten, konstruk dan individu. Validitas konten dilakukan agar produk pengembangan soal UMPTKIN tidak mengalami kesalahan konseptual. Validitas konstruk dilakukan untuk memastikan bahwa instrumen assesmen mampu memberdayakan keterampilan HOTS mahasiswa. Terakhir, validitas individu (mahasiswa, dosen, penguji, dan sebagainya) ditujukan untuk kelayakan instrumen penilaian. ${ }^{22}$ Ketiga hal di atas harus didistribusikan secara merata pada soal UM-PTKIN. Idealnya sekelas soal ujian masuk perguruan tinggi baik perguruan tinggi keislaman maupun umum harus menyentuh aspek HOTS secara keseluruhan. Namun, ternyata di lapangan masih ditemukan soal UM-PTKIN sebagaimana diwartakan data di atas. Tentu hal ini sangat miris dan semakin memperburuk mutu pendidikan Indonesia atau -meminjam istilah Raihani- telah terjadi ketidakadilan sosial (social injustice) ${ }^{23}$ dalam soal UM-PTKIN.

Sentralisasi salah satu aspek HOTS dalam soal UM-PTKIN, mengamanatkan bahwa soal UMPTKIN sebagai instrument penjaringan mahasiswa baru harus dikembangkan berdasarkan notasi empat kemampuan inti dalam kurikulum 2013 (K13), yaitu spiritual (KI-1), sosial (KI-2), pengetahuan (KI-3), dan

\footnotetext{
${ }^{19}$ Nurdinah Hanifah, Pengembangan Instrumen Penilaian Higher Order Thinking Skill, 5.

${ }^{20}$ Gregory Schraw and Daniel H. Robinson (Ed.), Assessment Of Higher Order Thinking Skills (USA, North Carolina: Information Age Publishing, 2011), 1.

${ }^{21}$ Ibid., 20.

${ }^{22}$ Ahmad Walid, et al, "Construction of The Assessment Concept To Measure Students' High Order Thinking Skills", Journal for the Education of Gifted Young Scientists 7 (2019): 244.

${ }^{23}$ Raihani, "A Model Of Islamic Teacher Education For Social Justice In Indonesia: A Critical Pedagogy Perspective," Journal Of Indonesian Islam 14, no. 1 (1 Juni 2020): 163-186, https://doi.org/10.15642/JIIS.2020.14.1.163-186
} 
Lilik Huriyah, Muhammad Fahmi, Rohaizan Baru, Wahyu llaihi

keterampilan (KI-4). Intinya, mahasiswa mengkonstruksi pengetahuan, pemahaman dan kesadarannya sendiri melalui interaksi yang penuh tantangan dengan komprehensitas soal UM-PTKIN guna mengasah ketajaman berpikir dan memecahkan problematika kehidupan. Hal ini menyiratkan bahwa penyusunan soal UMPTKIN saling berkelindan dengan segala lini termasuk mahasiswa itu sendiri.

Dalam konteks pendidikan Islam, sahabat Umar bin Khattab tatkala menulis untuk penduduk daerah Hims, "ajarilah anak-anak kalian berenang, memanah dan menunggang kuda". Sedangkan sabda Nabi saw yang lain, 'Uqbah bin ‘Amir al-Juhani sebagaimana termaktub dalam Shahih Muslim, "Siapapun yang telah diajarkan memanah dan kemudian meninggalkannya maka dia bukan golongan kami atau telah durhaka terhadap Nabi". (H.R. Muslim). ${ }^{24}$ Lebih jauh, sahabat Ali bin Abi Thalib secara eksplisit menegaskan pentingnya mendidik anak sesuai dengan zamannya, "didiklah anak-anakmu sesuai zamannya, sebab mereka akan mengalami zaman yang berbeda denganmu". Bahkan statemen Ali "disitasi" oleh Socrates, "jangan paksakan anak-anakmu mengikuti jejakmu, mereka diciptakan untuk kehidupan di zaman mereka, bukan zamanmu".

Beberapa pesan nubuwwah, perkataan sahabat dan filosof Barat melambangkan bahwa pendidikan di zaman itu dilaksanakan sesuai dengan zamannya. Jika ditarik ke dalam konteks sekarang, penyusunan soal UM-PTKIN tidak boleh berkutat pada paradigma lama atau sentralisasi salah satu aspek, melainkan harus komprehensif dan disesuaikan dengan gradasi tingkat berpikir individu. Mahasiswa harus diterapkan dan dilatih sesering mungkin untuk berpikir pada tingkatan tertinggi HOTS, yakni C6 (mengkreasikan). Mereka sebagai agent of change dan penerus masa depan bangsa Indonesia harus ditempa sedemikian rupa melalui soal-soal berbasis C6 (mengkreasikan) sehingga mampu menahkodai bangsa ini dengan new mind, new habit and new personality. Itulah hakikat new normal.

Oleh karena itu, pemerataan aspek HOTS mulai C1 sampai C6 dalam soal UM-PTKIN sebagai entry point penjaringan mahasiswa baru mendapat legitimasinya dari khazanah Islam, Al-Quran dan alHadith. Kedua khazanah induk Islam tersebut menyarankan bahwa keadilan haruslah menjadi pondasi utama dalam kehidupan manusia, tidak terkecuali pemerataan aspek HOTS dalam soal-soal UM-PTKIN. Soal-soal UM-PTKIN harus dikembangkan dan dirancang secara keseluruhan untuk mendorong pemikiran kritis, inovasi dan kreativitas, serta keadilan berpikir dan berperilaku. Secara sederhana, keseluruhan aspek HOTS harus ter-deliver secara distributif, bukan parsialistik. Seperti dijelaskan di awal, UM-PTKIN adalah gerbang masuk bagi PTKIN untuk menjaring mahasiswa baru yang berkualitas. Seleksi UM-PTKIN yang baru saja dibuka di tahun ajaran baru 2021 tampaknya harus adaptif dengan konteks kekinian. Jika tidak, jangan berharap PTKIN dapat memperbaiki bahkan meningkatkan kualitasnya termasuk dosen dan mahasiswanya- demi menyongsong Indonesia Emas 2045.

Sebagai rekomendasi dari kajian ini, pada tahun berikutnya, para penyusun soal-soal UM-PTKIN, perlu meningkatan level soal HOTS Materi PAI khususnya mata uji Al-Quran Hadith. Hal ini sangat

\footnotetext{
${ }^{24}$ Abdullah al-Qayrawani, al-Nawadir wa al-Ziyadat (Beirut: Dar al-Gharib al-Islami, tt), Juz 3, 39.
} 
diperlukan karena soal Al-Quran Hadith masih $80 \%$ berupa soal LOTS. Dengan adanya soal-soal yang HOTS, maka hal ini merupakan pintu masuk yang sangat baik bagi perguruan tinggi untuk dapat melaksanakan proses pendidikan seoptimal mungkin. Apalagi Prodi PAI di PTKIN termasuk dalam kategori favorit dengan peminat tingkat tinggi. Ketika soal-soal UM-PTKIN semuanya ber-level HOTS, maka mahasiswa yang terseleksi juga dapat terjamin kualitasnya. Jika input yang masuk berkualitas, maka raw input dan proses pembelajaran di dalamnya juga berkualitas, dan akhirnya berujung pada mutu lulusan yang baik dan berkualitas tinggi (high quality). Hal ini diharapkan dapat membawa dampak pada peningkatan akreditasi program studi, Perguruan Tinggi, dan mutu kualitas pendidikan Islam secara nasional yang excellent.

Dalam mendukung terwujudnya perubahan seperti yang diharapkan di atas, kertas kerja ini menyarankan tiga hal esensial. Pertama, menerapkan aspek (C6 atau mengkreasikan) dengan persentase 70\%, aspek C4-C5 sebanyak 20\%, dan C1-C3 sebanyak 10\%. Pada tingkat C6 (mengkreasikan) bentuk soalnya antara lain, tentang merekonstruksi, merumuskan, memadukan, mengombinasikan, menyusun, menghubungkan. Sedangkan tingkat C4-C5 bentuk soalnya terkandung aspek berikut ini, yakni menganalisis, mengkritisi, menyeleksi, menyimpulkan, menilai, mengomparasikan, menelaah, merasionalkan dan memperjelas. Adapun C1-C3 sebagai bagian dari LOTS, kandungan soalnya mencakup sebagai berikut, menyebutkan, menjelaskan, mengimplementasikan, mengklasifikasikan, mengoperasikan, dan kata kerja sejenisnya. ${ }^{25}$

Komposisi HOTS di atas -mengutip Anderson dan Krathwohl- menjadi assesmen untuk mengingat sekaligus transfer of knowledge and value. Assesmen soal tentu tidak hanya berkutat pada aspek mengingat (remembering) saja, melainkan memerlukan pengetahuan atau dalam istilah Anderson, HOTS as transfer of knowledge and value (HOTS sebagai transfer pengetahuan dan nilai). Selanjutnya, HOTS as critical thinking (HOTS sebagai berpikir kritis). Berpikir kritis dalam arti berpikir relfektif dan logis serta concern pada pemutusan masalah. Norris dan Ennis menyebut sebenarnya tujuan assesmen berbasis HOTS terletak pada aspek ini. ${ }^{26}$ Dalam hal ini, calon mahasiswa dapat mengorkestrasikan berbagai pengetahuannya kemudian mengkritisinya dengan argumen yang beralasan.

Lebih jauh, HOTS juga berfungsi sebagai problem solving (pemecahan masalah). Dewasa ini calon mahasiswa harus ditempa sedini mungkin untuk dilatih memecahkan masalah. Sebab era disrupsi dan pandemi Covid-19 (new normal) menuntut seseorang untuk mampu mengatasi berbagai kesulitan yang ada. Maka, jika soal UM-PTKIN PAI yang terdiri dari Akidah Akhlak, Al-Quran Hadith, Sejarah Kebudayaan Islam, Fiqih, hanya sedikit yang memuat aspek soal terkait problem solving, maka kemampuan calon mahasiswa tak ubahnya seperti bayi yang harus selalu dituntun. Ini tentu bukan harapan kita bersama. ${ }^{27}$

\footnotetext{
${ }^{25}$ Arthur Lewis \& David Smith, "Defining Higher Order Thinking," Theory into Practice 32.3 (1993), 131.

${ }^{26}$ Susan M. Brookhart, How to Assess Higher-Order Thinking Skills in Your Classroom (USA: ASCD, 2010), 3-9.

27 Ibid.
} 
Lilik Huriyah, Muhammad Fahmi, Rohaizan Baru, Wahyu llaihi

Kedua, mengevaluasi ulang seluruh soal-soal UM-PTKIN, mana aspek yang masih banyak terkandung LOTS daripada HOTS. Berpijak data di atas, AI-Quran Hadith paling banyak memuat LOTS (80\%) ketimbang HOTS (20\%). Seyogyanya soal materi ini harus dievaluasi ulang. Kemudian, menyisir soal-soal pada keempat materi PAI lainnya untuk memastikan komposisi 70\% untuk C6, 20\% untuk C4C5 dan 10\% untuk C1-C3 terimplementasi dengan benar dan baik.

Ketiga, Kementerian Agama sebagai leading sector sekaligus pilot project harus membentuk tim kecil yang terdiri dari profesor, doktor, civitas akademika dan pakar assesmen evaluasi soal untuk menyeleksi soal-soal UM-PTKIN dan menyesuaikannya dengan konteks kekinian, era 5.0 dan pandemi Covid-19, misalnya. Adapun langkah lain yang dapat dilakukan adalah dengan memberikan worskhop dan pelatihan agar pemangku kepentingan terkait memiliki kapastias untuk terlibat aktif dalam penyusunan soal HOTS. Proses tersebut, kata Raihani, akan mengikuti logika perubahan, yaitu inisiasi, implementasi dan institusi (PTKIN) terkait. Tidak terpisahkan, sinergitas antar kementerian, lembaga dan ormas keagaman Islam mainstream (Nahdlatul Ulama dan Muhammadiyah) menjadi underpinning factor yang tidak boleh dilupakan.

\section{F. Kesimpulan}

Tingkat Berpikir kognitif dalam taksonomi Bloom dibedakan menjadi dua, yakni level Higher Order Thinking Skills (HOTS) dan Lower Order Thinking Skill (LOTS). Adapun yang termasuk dalam kategori tingkat berpikir kognitif level rendah atau LOTS adalah menghafal (C1), memahami (C2), dan mengaplikasi (C3). Sedangkan berpikir kognitif tingkat tinggi atau HOTS adalah menganalisis (C4), mengevaluasi (C5) dan Mengkreasi (C6). Tuntutan kemampuan berpikir kognitif level C1 hingga C6 ini terdapat dalam soal UM-PTKIN tahun 2018 materi Pendidikan Agama Islam. Secara umum, soal UMPTKIN tahun 2018 terdiri dari soal Tes Kemampuan Dasar (TKD) dan Tes Kemampuan Bidang (TKB) yakni IPA atau IPS. Dalam soal TKD terdapat beberapa soal yakni soal Tes Potensi Akademik (TPA), Bahasa Inggris, bahasa Arab, dan PAI. Soal materi PAI terdiri dari kajian Al-Quran Hadith, Akidah Akhlak, Sejarah Kebudayaan Islam (SKI), dan Fiqh. Terdapat sejumlah 45 soal PAI dalam soal UMPTKIN Tahun 2018.

Dari keseluruhan soal UM-PTKIN tahun 2018 materi PAI tersebut terdapat soal level HOTS dan soal level LOTS. Dari jumlah keseluruhan soal PAI yang terdapat 45 butir soal, terdapat 34 butir soal HOTS atau setara dengan $75,6 \%$. Sedangkan soal-soal bertaraf LOTS pada soal UMPTKIN materi PAI pada tahun 2018 berjumlah 11 butir soal yang setara dengan 24,4 \%. Soal HOTS paling banyak adalah soal tentang Akidah Akhlak, sedangkan yang paling sedikit HOTS-nya adalah soal Al-Quran Hadith. Soal Mata uji Akidah akhlak menyumbangkan soal HOTS sebanyak $89 \%$, soal mata uji Sejarah Kebudayaan Islam memuat soal HOTS sebayak 88\%, mata uji Fiqh memuat soal HOTS sebanyak $73 \%$, dan mata uji Al-Quran Hadith memuat soal HOTS sebanyak $20 \%$.

Pada tahun berikutnya, para penyusun soal-soal UM-PTKIN, perlu meningkatan level soal HOTS Materi PAI khususnya mata uji Al-Quran Hadith. Hal ini sangat diperlukan karena soal Al-Quran Hadith 
masih $80 \%$ berupa soal LOTS dan $20 \%$ berupa soal HOTS. Dengan adanya soal-soal yang HOTS, maka dapat menjadi pintu masuk yang sangat baik bagi perguruan tinggi untuk dapat melaksanakan proses pendidikan seoptimal mungkin. Jika input yang masuk berkualitas, maka proses pembelajaran di dalamnya (raw input) juga berkualitas, dan akhirnya berujung pada mutu lulusan (output dan outcome) yang berkualitas tinggi. Hal ini dapat berdampak pada meningkatnya akreditasi program studi dan Perguruan Tinggi yang unggul (excellent).

\section{G. Referensi}

Anasy, Zaharil, HOTS (Higher Order Thinking Skilll in Reading Exercise, TARBIYA: Journal of Education in Muslim Society, Volume 3 Number 1, 2016.

Alfin, Jauharoti, Ah. Zakki Fuad, et.al., Development of Group Science Learning (GSL) Model to Improve the Skills of Collaborative Problem Solving, Science Process, and Self Confidence of Primary Schools Teacher Candidates, International Journal of Instruction, Volume 12, Number 1, January 2019.

Arikunto, S. Dasar-Dasar Evaluasi Pendidikan. Jakarta: PT Bumi Aksara, 2009.

Arifin, Z., Evaluasi Pembelajaran, Cetakan ke-dua (Edisi Revisi). Bandung: PT Remaja Rosdakarya, 2009.

Basuki, MS Hariyanto, Asesmen Pembelajaran, Bandung, PT Remaja Rosda karya, 2016.

Brookhart, Susan M. How to Assess Higher-Order Thinking Skills in Your Classroom. USA: ASCD, 2010.

Daryanto. Evaluasi Pendidikan. Jakarta: Rineka Cipta, 2001.

De Burin, Anique B.H., Jeroen J.G. van Meerenboer, Bridging Cognitive Load and Self-Regulated Learning Research, Learning and Instruction, Volume 51, 2017.

Dinni, Husna Nur, HOTS (High Order Thinking Skills) dan Kaitannya dengan Kemampuan literasi mahasiswa, Prisma, Prosiding Seminar Nasional Matematika, 2018.

Enggar, Belajar Tiada Henti, Kata Kerja Operasional (Baru) Taksonomi Bloom dalam http://enggar.net/2016/06/kata-kerja-operasional-baru-taksonomi-bloom/

Fabrika Pasandaran, Rio, Desak Made Ristia Kartika, High Order Thinking Skills (HOTS) Pembelajaran Matematika Kontemporer, Pedagogy, Jurnal Pendidikan Matematika, Volume 4, Nomor 1, 2019.

Fahmi, Muhammad, Tantangan interkoneksi Sains dan Agama di IAIN Sunan Ampel, JPAI Jurnal Pendidikan Agama Islam, Volume 02, Nomor 02, November 2013.

Fanani, Achmad, Pengembangan Pembelajaran Berbasis HOTS (High Order Thinking Skill) di Sekolah Dasar Kelas V, JPD Jurnal Pendidikan Dasar, tt.

Fatkhan, Bloom's Taxonomy dalam http://fatkhan.web.id/taksonomi-bloom/.

Fuad, Ah. Zakki, Taksonomi Transenden (Paradigma Baru Tujuan Pendidikan Islam), JPAl Jurnal Pendidikan Agama Islam, Volume 02 Nomor 01 Mei 2014.

Fuad, Ah. Zakki, Desain materi Pendidikan kosmologi (Kawniyyah) Perspektif Al-Quran, JPAI, Jurnal Pendidikan Agama Islam, Volume 3, Nomor 01, Mei 2015.

Gayatri. Metode Penelitian Pendidikan. Jakarta: Gaung Persada, 2010.

Hanifah, Nurdinah, Pengembangan Instrumen Penilaian Higher Order Thinking Skill (HOTS) di Sekolah Dasar, Current Research in Education: Conference Series Journal, Vol. 1, No. 1 Tahun 2019.

Inankito, Pengertian dan Contoh Soal HOTS, 2016 dalam http://www.inankito.org/2016/11/pengertiandan-contoh-soal-HOTS.html.

Ishak, Kozikoglu, Investigating Critical Thinking in Prospective Teachers: Metacognitive Skills, Problem Solving Skills and Academic Self-Efficacy, JSSER, Journal of Social Studies Education Research, Volume 10, Number 2, 2019.

Iswinarti, Gerdaning Tyas Jadmiko \& Nida hasanati, Cognitive Emotion Regulation: Its Relationship to Parenting Stress, JSSER, Journal of Social Studies Education Research, Volume 11, Number 2, 2020.

Javadi, Mohammad Mohammadi. The Effect of Critical Discourse-Based Instruction on Iranian English Major Students' Reading Comprehension. International Journal of Instruction, Volume 12, Number 1, January 2019. 
Jihad, Asep \& Abdul Haris. Evaluasi Pembelajaran. Yogyakarta: Multi Pressindo, 2012.

Lewy, Z dan Nyimar, A. Pengembangan Soal untuk Mengukur Kemampuan Berpikir Tingkat Tinggi Pokok Bahasan Barisan dan deret Bilangandi Kelas IX Akselerasi SMP Xaverus Maria Palembang, Jurnal Pendidikan Matematika, Vol. 3. No. 2, Palembang, UNSRI. 2009.

L. W. Anderson dan D.R. Krathwohl, A Taxonomy for Learning, Teaching, and Assesing, A revision of Bloom's Taxonomy of Education Objectives, New York: Addison Wesley Lonman Inc, 2001.

Lewis, Arthur \& David Smith. "Defining higher order thinking," Theory into Practice. 32.3 (1993).

Maimunah, Finanta Rastic Andrari, Nurmala Dewi Qadarsih, Analisis Higher Order Thinking Skills (HOTS) Calon Gru Matametika ditinjau dari Gaya Belajar, SAP, Susunan Artikel Pendidikan, Volume 4, Nomor 3 April 2020.

Nadlir \& Hanik Yuni Alfiyah. "Perbandingan Pendekatan Saintifik antara Kurikulum 2013 dan Pendekatan Burhani dalam Peningkatan Keterampilan Berpikir Tingkat Tinggi pada Mata Pelajaran Fiqih". Jurnal Pendidikan Agama Islam (Journal of Islamic Education Studies). Vol. 6, No. 1, 2018.

Nganga, Lydiah, Preservice Teachers Persceptions of Teaching for Global Mindedness and Social Justice: Using the 4Cs (Collaboration, Critical Thinking, Creativity and Communication) in Teacher Education, Journal of Social Studies Education Research, Volume 10, Number 4, 2019.

Pendaftaran mahasiswa baru, dalam https://www.populer.web.id/2015/05/pendaftaran-mahasiswabaru.html.

Qayrawani (Al), Abdullah. Al-Nawadir wa al-Ziyadat. Beirut: Dar al-Gharib al-Islami, tt. Juz 3.

Rachmawati, Eka, Anti Kolonial Prodjosantoso, et.al., Next Generation Science Standard in Science Learning to Improve Student's Practice Skill, International Journal of Instruction, Volume 12, Number 1, January 2019.

Raihani, "A Model Of Islamic Teacher Education For Social Justice In Indonesia: A Critical Pedagogy Perspective". Journal of Indonesian Islam, 14, No. 1 (1 Juni 2020), https://doi.org/10.15642/JIIS.2020.14.1.163-186.

Saifuddin, Ahmad, Eksistensi Kurikulum Pesantren dan Kebijakan Pendidikan, JPAI Jurnal Pendidikan Agama Islam, Volume 3, Nomor 01, Mei 2015.

Schraw, Gregory and Daniel H. Robinson (Ed.). Assessment Of Higher Order Thinking Skills. USA, North Carolina: Information Age Publishing, 2011.

Sudijono, Anas. Pengantar Evaluasi Pendidikan. Jakarta: Raja Grafindo Persada, 2008.

Sugiyono. Metode Penelitian Pendidikan: Pendekatan Kuantitatif, Kualitatif, dan R\&D, Bandung: Alfabeta, 2010.

Sukardi. Evaluasi Pendidikan: Prinsip dan Operasionalnya. Jakarta: Bumi Aksara, 2008.

Suyono \& Hariyanto. Belajar dan Pembelajaran: Teori dan Konsep Dasar. Bandung: Remaja Rosdakarya, 2014.

Walid, Ahmad, et al. "Construction of The Assessment Concept To Measure Students' High Order Thinking Skills". Journal for the Education of Gifted Young Scientists 7 (2019).

Zenius, Taxonomy Bloom, dalam https://twitter.com/zeniuseducation/status/ $1169527196341268480 /$ photo/1. 